\title{
Social determinants and risk behaviors associated with prevalent Hepatitis $C$ and HIV/HCV co-infection among male injection drug users in Nepal
}

\author{
Sampurna Kakchapati ${ }^{1 *}$, Manju Maharjan², Bir Bahadhur Rawal ${ }^{3}$ and Sameer Mani Dixit ${ }^{4}$
}

\begin{abstract}
Background: Nepal is facing double burden of injecting drug use and HIV, yet the problem of Hepatitis C Virus (HCV) has not been so well addressed, where there is large population known to be at risk for HCV. This study assessed the prevalence of HCV infection and HIV/HCV co-infection among male injection drug users (IDUs) in Nepal and identified factors associated with infection.

Methods: Cross-sectional surveys in 2015 aimed to sample 1045 male IDUs in the Kathmandu valley, Pokhara Valley and Eastern Terai districts of Nepal. Information about socio demographic characteristics, injecting and sexual risk behaviours were obtained, and biological specimens tested for HCV and HIV. The logistic regression model was used to identify the determinants associated with HCV and HIV/HCV co-infection.

Results: HCV prevalence was $28.8 \%$ and HIV/HCV co-infection was $4 \%$. Among the $6 \%$ of HIV positive male IDUs, $65 \%$ were found to be co-infected. The multivariate logistic analysis revealed that HCV prevalence was higher in Eastern Terai districts, longer duration of drug use and injecting drugs and presence of HIV. Similarly, HIV/HCV coinfection was associated with Eastern highway districts, older age and longer duration of injecting drugs.

Conclusion: The factors strongly contributing to HCV and HIV/HCV co-infection was longer duration of injecting drugs. Highest HCV and HIV/HCV co-infection was found in Eastern Terai districts. Target health interventions need to be focused in Eastern Terai districts and IDUs with longer duration of injecting drugs for the prevention of HCV and HIV/HCV transmission.
\end{abstract}

Keywords: Hepatitis C, HIV, IBBS, Drug users, Nepal

\section{Background}

Human Immunodeficiency Virus (HIV) and Hepatitis C virus $(\mathrm{HCV})$ are a major public health concern among male injection drug users (IDUs) worldwide [1, 2]. An estimated 130-150 million people are chronically infected with $\mathrm{HCV}$ infection causing half million deaths and the majority of cases occurred in low and middleincome countries [1-3].

IDUs are disproportionately affected by the HCV epidemic and bear by far the greatest burden of $\mathrm{HCV}$ of

\footnotetext{
* Correspondence: sampurna.k@psu.ac.th; kck_sampurna@yahoo.com ${ }^{1}$ Department of Mathematics and Computer Science, Faculty of Science and Technology, Prince of Songkla University, Pattani, Thailand

Full list of author information is available at the end of the article
}

any population $[1,2,4]$. Among the estimated 16 million IDUs globally, about 8 million suffered from chronic hepatitis [4]. Injecting drug use accounts for $67 \%$ of $\mathrm{HCV}$ infections [5]. Co-infection with HIV is prevalent among IDU [4-6] and in fact, HCV has become a leading cause of death among HIV-positive people. $\mathrm{HCV} /$ HIV co-infection can rapid the progression of HCV [7], and co-infected people have lesser life expectancy [8]. $\mathrm{HIV} / \mathrm{HCV}$ co-infection complicates anti-retroviral therapy (ART) for treatment of HIV infection, as several anti-retroviral drugs are poorly tolerated by co-infected patients. Early detection of co-infection is optimal so that HCV treatment can be commenced before initiation of ART [9]. 
In Nepal, there are about that 50,000 people injected drugs and HIV and HCV are a major burden among IDUs in the region [10-12]. Although, HIV among male IDUs has significantly decreased from $68 \%$ in 2002 to 6.4\% in 2015 in Kathmandu Valley, IDUs are still the most key affected population compared to other groups with respect to HIV infections [10-12]. Multiple studies provide evidence that $\mathrm{HCV}$ prevalence is rapidly increased among male IDUs [4-6]. In Nepal the recent study in 2015 showed that the prevalence rate of $\mathrm{HCV}$ among male IDUs was $41.9 \%$ [10]. Sharing needles/syringes between injecting partners and re-use of needles kept in public places retain high-risk behavior among IDUs $[1,2]$. Moreover, risk factors include use of unsterilized medical equipment, the transfusion of unscreened blood and blood products and social or cultural practices comprising of body piercing, circumcision, and tattooing [1, 13-16]. Sexual behaviour such as unprotected sex with sexual partners is also considered as risk for HCV [14]. HCV prevalence was higher among persons with multiple sexual partners or risk for sexually transmitted diseases than persons with durable faithful relationship [17-19]. However the risk is also linked with rates of exposure to nonsexual sources of $\mathrm{HCV}$, such as injection drug use or shared razors and toothbrushes [17].

Although studies revealed that social determinants and risk behaviours are linked with $\mathrm{HCV}$ infection and HIV/ HCV co-infection globally [4-6, 9, 13-19], limited studies associated with HCV prevalence among IDUs were documented in Nepal. The aim of the study was to assess HCV prevalence and HIV/HCV co-infection and social and behavioural factors associated with $\mathrm{HCV}$ prevalence and $\mathrm{HIV} / \mathrm{HCV}$ co-infection among male IDUs in Nepal using Integrated Biological and Behavioral Surveillance (IBBS) survey data. In Nepal, IBBS surveys are regularly conducted among male IDUs from 2002 to 2015 to understand the emerging trends of HIV and HIV related risk behaviours, while there was no routine surveillance for HCV infection. This recent IBBS surveys in 2015 assessed HCV prevalence among male IDUs in Eastern Terai districts, Kathmandu Valley and Pokhara Valley of Nepal for the first time.

\section{Methods}

A cross sectional study was conducted in the Kathmandu Valley, Pokhara Valley and Eastern Terai districts by the National Centre for AIDS and STD Control (NCASC) in 2015. In this study IDUs were defined as males, aged 16 years and above using injecting illicit drugs for at least three months prior to the date of the survey. About 340 male IDUs were recruited from Kathmandu Valley, 345 recruited from Pokhara Valley and 360 recruited from Eastern Terai Districts. The duration of study was from March to September 2015. IBBS surveys used respondent driven sampling (RDS) to select male IDUs in Kathmandu valley and Pokhara valley. Two stage cluster sampling was used to recruit male IDUs in Eastern Terai districts.

Face-to-face interviews were conducted by trained field workers in local language, Nepali, using a structured questionnaire. The independent variables for the study were socio-determinants (age, region, education, marital status), drug injecting practices (age of first drug injection, duration of drug use and injecting drugs, used needle/syringe previously used by someone else in past week, used syringe/needle left in a public place in past week, and shared needle/syringe with someone after using in past week) and sexual behaviors (age at first intercourse, number of sexual partners, number of FSWs) and consistent condom use with different sex partners. The sex partners were regular female sex partners, female sex workers (FSWs), and non-regular female sex partners. Regular female sex partner is spouse or any sexual partner living together with IDUs. FSWs were defined as those who sell sex in exchange for cash, kind, or drugs. Non-regular female sex partners were girlfriends or other female friends with whom IDUs have sexual relationship with but IDUs were neither married nor living together. The outcome variables for the study were $\mathrm{HCV}$ prevalence and HIV/HCV co-infection.

Informed consent was obtained from IDUs prior to the interview. There may be a risk of identifying the IDUs through their signatures if written consent was taken. The informed consent was taken in the presence of a witness (community motivators) who then signed the consent form. Study procedure was designed to protect participants' privacy allowing for anonymous and voluntary participation. No names and personal identifiers were used in the data collection. Ethical clearances were permitted from Nepal Health Research Council.

Biological specimens were detected for HIV and HCV. Detection of HIV infection was carried out through rapid test kits following the HIV testing strategy II algorithm, which is based upon the "National Guidelines for Voluntary HIV and AIDS Counseling and Testing 2007". HIV was detected through the use of 'Determine HIV 1/ 2 (Abbott Japan Co. Ltd.)' rapid test kits as a first test to detect antibodies against HIV. If the first test showed a negative result then no further tests were conducted. However, if the first test result was positive, the second test was performed using 'Uni-Gold (Trinity Biotech, Dublin, Ireland)' test kits. In cases of a tie between the first two tests, a third test was performed using 'Stat Pak HIV 1/2 (Standard Diagnostics, Inc., Kyonggi-do, South Korea)' as a tie-breaker test.

Dried blood spot samples were tested for the presence of antibodies against $\mathrm{HCV}$ by Blood/Serum/Plasma 
Dipstrip (Orgenics, Israel). The RapidSignal HCV whole blood/serum/plasma dipstrip kit was maintained under refrigeration. The kit components (dipstrips and buffer) were brought to room temperature. To begin the testing, the test dipstrip was removed from a sealed foil pouch. The tape was peeled off from the test stripe card and the dipstrip was stuck in the middle of the test card with arrows pointing down on the test card. Then, plasma sample was pipetted out and added onto the specimen pad of the dip strip. Then, two full drops of buffer were added and the timer was commenced. The sample was scored as reactive if two distinct red lines appeared- one in the control region and one in the test region. The sample was scored negative if the red line appeared only along the control line. If the red line did not appear at the control line irrespective of the test line, the test was considered invalid and the whole test was repeated using a new kit.

\section{Statistical analysis}

Chi-squared test was used to examine the association of social determinants and risk behaviors with $\mathrm{HCV}$ prevalence and $\mathrm{HIV} / \mathrm{HCV}$ co-infection. Logistic regression analyses were performed to determine factors associated with $\mathrm{HCV}$ and $\mathrm{HIV} / \mathrm{HCV}$ co-infection defined by combinations of the determinants. First, the univariate logistic model was carried out among determinants that were significant in the Chi-squared test. All determinants significant with $\mathrm{HCV}$ and $\mathrm{HIV} / \mathrm{HCV}$ co-infection prevalence in univariate logistic model were included the multivariate logistic model. This multivariate logistic model provides confidence intervals for outcomes for levels of each risk factor adjusted for other risk factors using sum contrasts methods. The confidence intervals based on sum contrast has an advantage that they provide a simple criterion for classifying levels of the factor into three groups according to whether each corresponding confidence interval exceeds, crosses, or is below the overall percent $[20,21]$. The confidence intervals compared percent of the specified cause group in each category with the overall percent [22]. Receiver Operating Characteristic (ROC) curve was used to measure of goodness-of-fit and constructed mosaic plot. ROC plots sensitivity against the false positive rate to show how well a model predicts a binary outcome. It also gives mosaic plot for comparing logistic regression models similar to $\mathrm{r}$-squared decomposition plot. $\mathrm{R}$ program was used for statistical analysis and creating graphs.

\section{Results}

A total of 1045 male IDUs were included in the analysis, of whom $28.8 \%$ of them tested positive for HCV. Table 1 depicts the association between social determinants, drug injecting behaviours, sexual behaviours and HIV with HCV. Region, age, marital status, history of imprisonment, age of first drug initiation, duration of drug use and injecting drugs, shared needle/syringe with someone after using in the past week, consistent condom use with regular sexual partners, consistent condom use with non-regular sexual partners and presence of HIV were significantly associated with $\mathrm{HCV}$ ( $p$-value $<0.001)$. By region, Eastern Terai districts had the highest prevalence (47.5\%) followed by Kathmandu Valley (22.1\%) and Pokhara Valley (16\%). HCV prevalence was found to be higher among older age groups; the prevalence being nearly half (45\%) among 30-39 years. HCV among the married was $40 \%$, higher than that of the unmarried population $(22 \%)$. The majority of male IDUs $(68 \%)$ was imprisoned or detained for any reasons and among them, $\mathrm{HCV}$ prevalence was $32 \%$. Risky drug injecting behaviors such as longer duration of drug use and injecting drugs, used needle/ syringe previously used by someone, used syringe/needle left in public place and shared needle/syringe to someone after you using it were common in this population. IDUs who had first drug initiation above 30 years (41\%) had higher HCV prevalence. HCV prevalence was higher among male IDUs whose duration of drug use and injecting drugs more than 10 years. IDUs who share needle/syringe to someone after used it in past week had higher HCV prevalence. IDUs who had consistent condom used with regular female sex partners had prevalence of $46 \%$ and inconsistent condom use with non-regular female sex partners had prevalence of $31 \%$. Among those $6.2 \%$ of male IDUs who were HIV positive, co-infection with $\mathrm{HCV}$ was high, with $64.6 \%$ being co-infected.

$\mathrm{HIV} / \mathrm{HCV}$ co-infection was prevalent in $4 \%$ of male IDUs. Region, age and duration of injecting drugs were associated with HIV/HCV co-infection ( $p$-value $<0.05$ ), as shown in Table 2. Eastern Terai districts had the highest $\mathrm{HIV} / \mathrm{HCV}$ co-infection (6.1\%) compared to Kathmandu Valley (5.3\%) and Pokhara Valley (0.6\%). $\mathrm{HIV} / \mathrm{HCV}$ co-infection was higher among older age groups (30 years and above) and longer duration of injecting drugs (more than 10 years).

In multivariate logistic regression, there was statistically significant association between the presence of $\mathrm{HCV}$ and region, duration of drug use and injecting drugs, and the presence of HIV. However, there is no causal inference to show region is associated with HCV. The study found the interaction between duration of drug use and injecting drugs, so these determinants were combined. The number of levels of the Injecting-Drug group factor depends on duration of drug use and injecting drugs and there were five levels. The results from fitting logistic model for $\mathrm{HCV}$ prevalence were shown in Fig. 1, with region, duration of drug use and injecting 
Table 1 Association between social determinants, drug injecting behaviours, sexual behaviours and HIV with Hepatitis $\mathrm{C}$

\begin{tabular}{|c|c|c|c|c|c|}
\hline \multirow[t]{2}{*}{ Characteristic } & \multirow{2}{*}{$\begin{array}{l}\text { Total }(n=1045) \\
n(\%)\end{array}$} & \multirow{2}{*}{$\begin{array}{l}\text { Hepatitis C }(n=301,28.8 \%) \\
n(\%)\end{array}$} & \multirow{2}{*}{$\begin{array}{l}\text { Not Hepatitis C }(n=744,71.2 \%) \\
n(\%)\end{array}$} & \multirow[t]{2}{*}{$x^{2}(d f)$} & \multirow[t]{2}{*}{$P$-value } \\
\hline & & & & & \\
\hline \multicolumn{4}{|l|}{ Region } & $96(2)$ & $<0.001$ \\
\hline Eastern Terai Region & $360(34.4)$ & $171(47.5)$ & $189(52.5)$ & & \\
\hline Kathmandu & $340(32.5)$ & $75(22.1)$ & $265(77.9)$ & & \\
\hline Pokhara & $345(33)$ & $55(15.9)$ & $290(84.1)$ & & \\
\hline \multicolumn{4}{|l|}{ Age } & $61(2)$ & $<0.001$ \\
\hline Below 20 years & $210(20.1)$ & $31(14.8)$ & $179(85.2)$ & & \\
\hline 20-29 years & $536(51.3)$ & $134(25.0)$ & $402(75.0)$ & & \\
\hline 30 years and above & $299(28.6)$ & $136(45.5)$ & $163(54.5)$ & & \\
\hline \multicolumn{4}{|l|}{ Education } & $3(2)$ & 0.17 \\
\hline No education & $25(2.4)$ & $7(28.0)$ & $18(72.0)$ & & \\
\hline Primary & $141(13.5)$ & $50(35.5)$ & $91(64.5)$ & & \\
\hline Secondary and above & $879(84.1)$ & $244(27.8)$ & $635(72.2)$ & & \\
\hline \multicolumn{4}{|l|}{ Marital status } & $40(1)$ & $<0.001$ \\
\hline Single & $654(62.6)$ & $143(21.9)$ & $511(78.1)$ & & \\
\hline Married & $391(37.4)$ & $158(40.4)$ & $233(59.6)$ & & \\
\hline \multicolumn{4}{|l|}{ History of Imprisonment } & $9.5(1)$ & 0.002 \\
\hline Yes & $677(64.7)$ & $217(32.1)$ & $460(67.9)$ & & \\
\hline No & $368(35.3)$ & $84(22.8)$ & $284(77.2)$ & & \\
\hline \multicolumn{4}{|l|}{ Age of drug initiation } & $6(2)$ & 0.03 \\
\hline Below 20 years & $614(58.8)$ & $179(29.2)$ & $435(70.8)$ & & \\
\hline 20-29 years & $360(34.4)$ & $93(25.8)$ & $267(74.2)$ & & \\
\hline 30 years and above & $71(6.8)$ & $29(40.8)$ & $42(59.2)$ & & \\
\hline \multicolumn{4}{|l|}{ Duration of drug use } & $85(3)$ & $<0.001$ \\
\hline Below 2 years & $331(31.7)$ & $44(13.3)$ & $287(86.7)$ & & \\
\hline $2-10$ years & $446(42.7)$ & $129(28.9)$ & $317(71.1)$ & & \\
\hline More than 10 years & $268(25.6)$ & $128(47.8)$ & $140(52.2)$ & & \\
\hline \multicolumn{4}{|l|}{ Duration of injecting drugs } & $113(3)$ & $<0.001$ \\
\hline Below 2 years & $553(53.0)$ & $91(16.5)$ & $462(83.5)$ & & \\
\hline $2-10$ years & $356(34.0)$ & $129(36.2)$ & $227(63.8)$ & & \\
\hline More than 10 years & $136(13.0)$ & $81(59.6)$ & $55(40.4)$ & & \\
\hline \multicolumn{4}{|c|}{ Used needle/ syringe previously used by someone in past week } & $2.1(1)$ & 0.157 \\
\hline Yes & $40(3.8)$ & $16(40)$ & $24(60)$ & & \\
\hline No & $1005(96.2)$ & $285(28.4)$ & $720(71.6)$ & & \\
\hline \multicolumn{4}{|c|}{ Use syringe/needle left in public place in past week } & $1.1(1)$ & 0.293 \\
\hline Yes & $16(1.5)$ & $7(43.8)$ & $9(56.2)$ & & \\
\hline No & 1029(98.5) & $294(28.6)$ & $735(71.4)$ & & \\
\hline \multicolumn{4}{|c|}{ Share needle/syringe to someone after you used it in past week } & $6.9(1)$ & 0.009 \\
\hline Yes & $47(4.5)$ & $22(46.8)$ & $25(53.2)$ & & \\
\hline No & $998(95.5)$ & $279(28)$ & $719(72)$ & & \\
\hline \multicolumn{4}{|l|}{ Age of first sex } & $2.5(1)$ & 0.117 \\
\hline Below 20 years & $865(82.7)$ & $240(27.7)$ & $625(72.3)$ & & \\
\hline Above 20 years & $180(17.3)$ & $61(33.9)$ & $119(66.1)$ & & \\
\hline
\end{tabular}


Table 1 Association between social determinants, drug injecting behaviours, sexual behaviours and HIV with Hepatitis C (Continued)

\begin{tabular}{|c|c|c|c|c|c|}
\hline \multicolumn{4}{|c|}{ Sexual contact with partners in past year } & \multirow[t]{3}{*}{$0.2(1)$} & \multirow[t]{3}{*}{0.740} \\
\hline Yes & $797(76.3)$ & $227(28.5)$ & $570(71.5)$ & & \\
\hline No & 248(23.7) & $74(29.8)$ & $174(70.2)$ & & \\
\hline \multicolumn{4}{|c|}{ Sexual contact with FSWs in past year } & \multirow[t]{3}{*}{$2.8(1)$} & \multirow[t]{3}{*}{0.090} \\
\hline Yes & 243(23.2) & $59(24.3)$ & $184(75.7)$ & & \\
\hline No & $802(76.8)$ & $242(30.2)$ & $560(69.8)$ & & \\
\hline \multicolumn{4}{|c|}{ Consistent condom use with regular sexual partners } & \multirow[t]{3}{*}{$35(1)$} & \multirow[t]{3}{*}{$<0.001$} \\
\hline Yes & $210(20.1)$ & $96(45.7)$ & $114(54.3)$ & & \\
\hline No & $835(79.9)$ & $205(24.6)$ & $630(75.4)$ & & \\
\hline \multicolumn{4}{|c|}{ Consistent condom use with FSWs } & \multirow[t]{3}{*}{$1.7(1)$} & \multirow[t]{3}{*}{0.193} \\
\hline Yes & 216(20.7) & $54(25)$ & $162(75)$ & & \\
\hline No & $829(79.3)$ & $247(29.8)$ & $582(70.2)$ & & \\
\hline \multicolumn{6}{|c|}{ Consistent condom use with non-regular sexual partners } \\
\hline Yes & $359(34.3)$ & $86(24)$ & $273(76)$ & \multirow[t]{2}{*}{$5.9(1)$} & \multirow[t]{2}{*}{0.015} \\
\hline No & $686(65.7)$ & $215(31.3)$ & $471(68.7)$ & & \\
\hline \multicolumn{4}{|c|}{ Consistent condom use with FSWs } & \multirow[t]{3}{*}{$1.7(1)$} & \multirow[t]{3}{*}{0.193} \\
\hline Yes & 216(20.7) & $54(25)$ & $162(75)$ & & \\
\hline No & $829(79.3)$ & $247(29.8)$ & $582(70.2)$ & & \\
\hline \multicolumn{4}{|l|}{ HIV } & \multirow[t]{3}{*}{$41(2)$} & \multirow[t]{3}{*}{$<0.001$} \\
\hline Yes & $65(6.2)$ & $42(64.6)$ & $23(35.4)$ & & \\
\hline No & $980(93.8)$ & $259(26.4)$ & $721(73.6)$ & & \\
\hline
\end{tabular}

drugs, and presence of HIV as determinants. Eastern Terai districts had the highest prevalence compared to Kathmandu Valley and Pokhara Valley of Nepal. Moreover, the HCV prevalence significantly increased with duration of drug use and injecting drugs. Higher prevalence was found among male IDUs who had longer duration of drug use and injecting drugs for more than 10 years. The presence of HIV was strongly correlated with $\mathrm{HCV}$.

\section{Receiver Operating Characteristic (ROC) Curve}

Figure 2 depicted ROC curves for the final model fitted to $\mathrm{HCV}$ prevalence. ROC curves provide the mosaic plot for comparing logistic regression models. The area under the curve (AUC) as 0.58 , indicating model performance is fitted. ROC curves show that model containing region, duration of drug use and injecting drugs, and the presence of HIV as determinants fits the prevalence data extremely well.

There was statistically significant association between the presence of HIV/HCV co-infection and age, region and duration of injection in multivariate logistic regression. Figure 3 shows results from fitting logistic model for $\mathrm{HIV} / \mathrm{HCV}$ co-infection. Higher $\mathrm{HIV} / \mathrm{HCV}$ coinfection was found in Eastern Terai districts, older age groups and had longer of injecting drugs.
Figure 4 showed ROC curves for the final model fitted to $\mathrm{HIV} / \mathrm{HCV}$ co-infection. The area under the curve (AUC) as 0.57 , indicating model performance is fitted.

\section{Discussion}

This study showed HCV infection was prevalent among male IDUs; however it was lower than recent study in 2015 that showed HCV prevalence of $41.9 \%$ [13]. The major concern was the high prevalence of $\mathrm{HCV}$ infection among those who were HIV infected (65\%), highlighting the importance of testing all HIV infected male IDUs for HCV before commencing ART.

There existed marked variation of $\mathrm{HCV}$ and $\mathrm{HIV} / \mathrm{HCV}$ co-infection, as $\mathrm{HCV}$ and $\mathrm{HIV} / \mathrm{HCV}$ prevalence was higher in Eastern Terai districts compared to Kathmandu Valley and Pokhara Valley. In Nepal, IDUs are confined in urban metropolises and eastern highway districts [23]. The territories of the Terai area are bordered to India and became a principal transit point for peddling drugs and provided an ideal passage for smugglers for decades [24]. Moreover, IBBS reports suggest that male IDUs in eastern highway districts are often poor, uneducated, came from rural areas, possessed unsafe injecting behaviors, had unprotected sexual contacts with sex workers and lacked access to local HIV/STI intervention compared to their counterparts in urban cities [25-28]. 
Table 2 Association between social determinants, drug injecting behaviours, sexual behaviors with HIV/HCV co-infection

\begin{tabular}{|c|c|c|c|c|c|}
\hline Characteristic & $\begin{array}{l}\text { Total }(n=1045) \\
\mathrm{n}(\%)\end{array}$ & $\begin{array}{l}\text { HIV/HCV co-infection }(n=42,4 \%) \\
\text { n (\%) }\end{array}$ & $\begin{array}{l}\text { Not HIV/HCV co-infection }(n=1003,96 \%) \\
\text { n (\%) }\end{array}$ & $x^{2}(d f)$ & $P$-value \\
\hline \multicolumn{4}{|l|}{ Region } & $16(2)$ & $<0.001$ \\
\hline Eastern Terai districts & $360(34.4)$ & $22(6.1)$ & $338(93.9)$ & & \\
\hline Kathmandu & $340(32.5)$ & $18(5.3)$ & $322(94.7)$ & & \\
\hline Pokhara & $345(33)$ & $2(0.6)$ & $343(99.4)$ & & \\
\hline \multicolumn{4}{|l|}{ Age } & $20(2)$ & $<0.001$ \\
\hline Below 20 years & $210(20.1)$ & $5(2.4)$ & $205(97.6)$ & & \\
\hline 20-29 years & $536(51.3)$ & $12(2.2)$ & $524(97.8)$ & & \\
\hline 30 years and above & $299(28.6)$ & $25(8.4)$ & $274(91.6)$ & & \\
\hline \multicolumn{4}{|l|}{ Education } & $0.1(2)$ & 0.988 \\
\hline No education & $25(2.4)$ & $1(4)$ & $24(96)$ & & \\
\hline Primary & $141(13.5)$ & $6(4.3)$ & $135(95.7)$ & & \\
\hline Secondary and above & $879(84.1)$ & $35(4)$ & $844(96)$ & & \\
\hline \multicolumn{4}{|l|}{ Marital status } & $6(1)$ & 0.011 \\
\hline Single & $654(62.6)$ & $18(2.8)$ & $636(97.2)$ & & \\
\hline Married & $391(37.4)$ & $24(6.1)$ & 367 (93.9) & & \\
\hline \multicolumn{4}{|l|}{ History of Imprisonment } & $2(1)$ & 0.157 \\
\hline Yes & $677(64.7)$ & $10(2.7)$ & $358(97.3)$ & & \\
\hline No & $368(35.3)$ & $32(4.7)$ & $645(95.3)$ & & \\
\hline \multicolumn{4}{|l|}{ Age of drug initiation } & $1.6(2)$ & 0.455 \\
\hline Below 20 years & $614(58.8)$ & $27(4.4)$ & $587(95.6)$ & & \\
\hline 20-29 years & $360(34.4)$ & $11(3.1)$ & $349(96.9)$ & & \\
\hline 30 years and above & $71(6.8)$ & $4(5.6)$ & $67(94.4)$ & & \\
\hline \multicolumn{4}{|l|}{ Duration of drug use } & $5(2)$ & 0.078 \\
\hline Below 2 years & $331(31.7)$ & $10(3)$ & $321(97)$ & & \\
\hline $2-10$ years & $446(42.7)$ & $15(3.4)$ & $431(96.6)$ & & \\
\hline More than 10 years & $268(25.6)$ & $17(6.3)$ & $251(93.7)$ & & \\
\hline \multicolumn{4}{|l|}{ Duration of injecting drugs } & $29(2)$ & $<0.001$ \\
\hline Below 2 years & $553(53.0)$ & $15(2.7)$ & $538(97.3)$ & & \\
\hline $2-10$ years & $356(34.0)$ & $10(2.8)$ & $346(97.2)$ & & \\
\hline More than 10 years & $136(13.0)$ & $17(12.5)$ & $119(87.5)$ & & \\
\hline \multicolumn{4}{|c|}{ Used needle/ syringe previously used by someone in past week } & $0.9(1)$ & 0.363 \\
\hline Yes & $40(3.8)$ & $42(4.2)$ & $963(95.8)$ & & \\
\hline No & $1005(96.2)$ & $0(0)$ & $40(100)$ & & \\
\hline \multicolumn{4}{|c|}{ Use syringe/needle left in public place in past week } & $1.2(1)$ & 0.272 \\
\hline Yes & $16(1.5)$ & $40(3.9)$ & $989(96.1)$ & & \\
\hline No & 1029(98.5) & $2(12.5)$ & $14(87.5)$ & & \\
\hline \multicolumn{4}{|c|}{ Share needle/syringe to someone after you used it in past week } & $0.1(1)$ & 0.768 \\
\hline Yes & $47(4.5)$ & $41(4.1)$ & $957(95.9)$ & & \\
\hline No & $998(95.5)$ & $1(2.1)$ & $46(97.9)$ & & \\
\hline \multicolumn{4}{|l|}{ Age of first sex } & $0.5(1)$ & 0.469 \\
\hline Below 20 years & $865(82.7)$ & $37(4.3)$ & $828(95.7)$ & & \\
\hline Above 20 years & $180(17.3)$ & $5(2.8)$ & $175(97.2)$ & & \\
\hline
\end{tabular}


Table 2 Association between social determinants, drug injecting behaviours, sexual behaviors with HIV/HCV co-infection (Continued)

\begin{tabular}{|c|c|c|c|c|c|}
\hline \multicolumn{4}{|c|}{ Sexual contact with partners in past year } & \multirow[t]{3}{*}{$0(1)$} & \multirow[t]{3}{*}{1} \\
\hline Yes & $797(76.3)$ & $10(4)$ & $238(96)$ & & \\
\hline No & $248(23.7)$ & $32(4)$ & $765(96)$ & & \\
\hline \multicolumn{4}{|c|}{ Sexual contact with FSWs in past year } & \multirow[t]{3}{*}{$0.1(1)$} & \multirow[t]{3}{*}{0.921} \\
\hline Yes & $243(23.2)$ & $33(4.1)$ & $769(95.9)$ & & \\
\hline No & $802(76.8)$ & $9(3.7)$ & $234(96.3)$ & & \\
\hline \multicolumn{4}{|c|}{ Consistent condom use with regular sexual partners } & \multirow[t]{3}{*}{$2.5(1)$} & \multirow[t]{3}{*}{0.111} \\
\hline Yes & $210(20.1)$ & $29(3.5)$ & $806(96.5)$ & & \\
\hline No & $835(79.9)$ & $13(6.2)$ & $197(93.8)$ & & \\
\hline \multicolumn{4}{|c|}{ Consistent condom use with FSWs } & \multirow[t]{3}{*}{$0(1)$} & \multirow[t]{3}{*}{1} \\
\hline Yes & 216(20.7) & $33(4)$ & $796(96)$ & & \\
\hline No & $829(79.3)$ & $9(4.2)$ & $207(95.8)$ & & \\
\hline \multicolumn{4}{|c|}{ Consistent condom use with non-regular sexual partners } & \multirow[t]{3}{*}{$0.9(1)$} & \multirow[t]{3}{*}{0.331} \\
\hline Yes & $359(34.3)$ & $31(4.5)$ & $655(95.5)$ & & \\
\hline No & $686(65.7)$ & $11(3.1)$ & $348(96.9)$ & & \\
\hline
\end{tabular}

Old age was associated with $\mathrm{HCV}$ infection in bivariate analysis and associated with $\mathrm{HIV} / \mathrm{HCV}$ coinfection in multivariate analysis. These results corroborate the outcomes of other studies demonstrating the increase of the $\mathrm{HCV}$ prevalence as age increases $[6,13]$. The prevalence of $\mathrm{HCV}$ and $\mathrm{HIV} / \mathrm{HCV}$ coinfection was found among aged 30 years and above. A recent study in Nepal showed that HCV prevalence correlated significantly with age [13]. A similar study in Brazil found that the HCV prevalence was highest over 30 years old, with a rise in patients aged 50 to 59 years (3.8\%) [29]. Moreover, the study also showed $\mathrm{HCV}$ infection was prevalent above 40 years old in Malaysia [30].
Moreover, $\mathrm{HCV}$ infection rates were higher among married IDUs. In the context of drug injecting practices, IDUs who had $\mathrm{HCV}$ can transmit the virus to their wives and other sexual partners. The combination of $\mathrm{HCV}$, drug use and sexual behaviors make them at high risk and an important source of infection to others. These IDUs should be reached by program and treated in order to prevent transmission to different sexual partners.

Imprisonment history was predictor for $\mathrm{HCV}$ infection in our study but these associations did not remain significant in the final multivariate analysis. These results were in accordance with studies showing $\mathrm{HCV}$ prevalence was higher among prisoners and

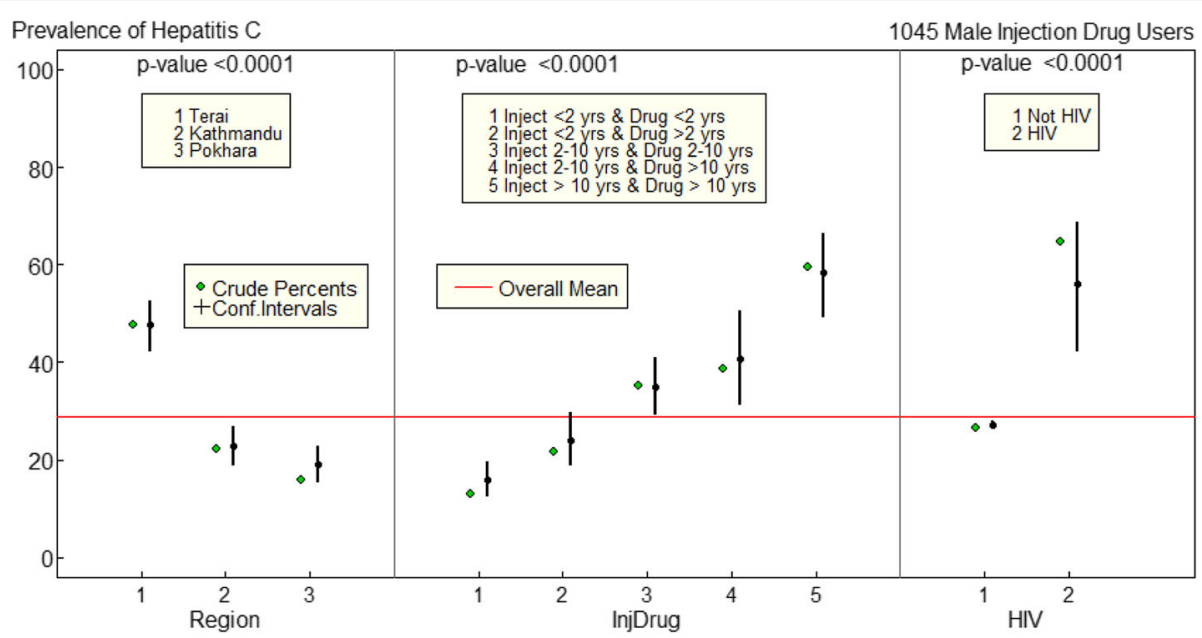

Fig. 1 Factors associated with HCV prevalence in multivariate logistic regression 

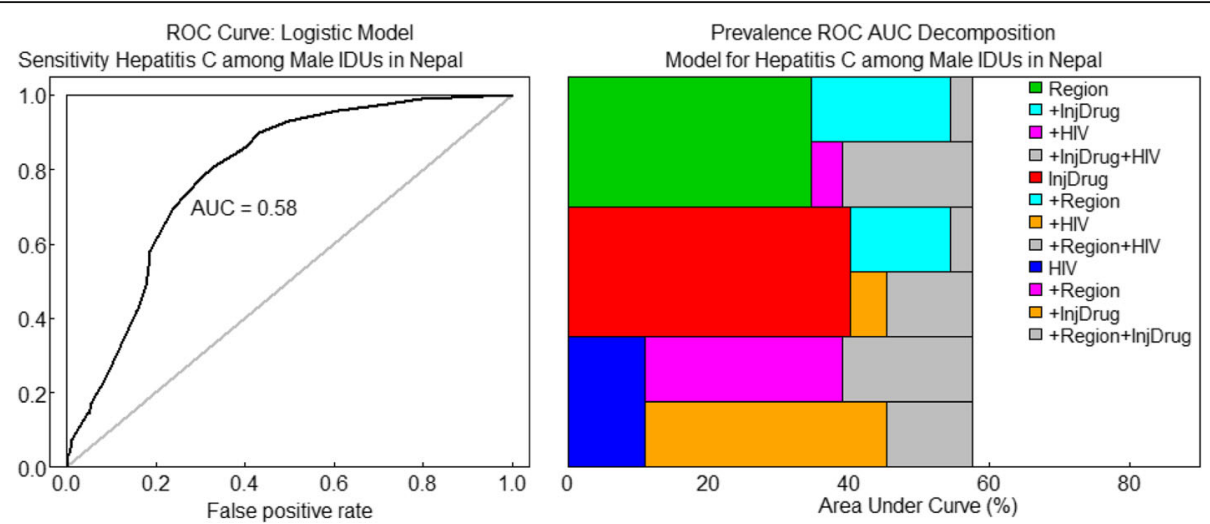

Fig. 2 ROC curve: Logistic Model for HCV among male IDUs in Nepal. Notes: InjDrug is duration of drug use and injecting drugs

ex-convicts [31, 32]. Studies reported high risk behaviors like drug abuse inside or outside the prisoners, which predispose the prisoners to infections of hepatitis B, C, and HIV [30, 31].

Consistent with previous studies, the established risk factors of duration of injection use were strongly related to $\mathrm{HCV}$ infections $[4,6-9]$. Longer duration of drug use and injecting drugs significantly increase risk for $\mathrm{HCV}$ and $\mathrm{HIV} / \mathrm{HCV}$ co-infection, and in a dose-dependent manner. The longer the IDUs are exposed to drug injecting behaviours, the more they are expose to greater numbers of injecting partners. The higher the concurrency of these partners, the more risk they are expose. Moreover, they are also more likely to engage in harmful alcohol use, substance abuse, sexual behaviours and contracting HIV infection when contact with a large number of partners $[4,13-16]$.

Unsafe injecting behaviors are the most common drug related risk behaviors, which puts the IDUs at risk of
$\mathrm{HCV}$ transmission. In our study, sharing needle/syringe to someone after using in past week was significantly associated with $\mathrm{HCV}$ prevalence in bivariate analysis. However, in multivariate analysis, no significant association was found. Previous studies delineated that unsafe injecting behaviour while preparing drug and practices of drug sharing among users (splitting drugs prepared by a user with subsequent transport of the prepared drug from one syringe to other syringe, sharing cotton, filters, cooker, water and water containers) were associated with HCV transmission [1, 2, 14-17].

In addition to this, sexual behaviour was also leading risk factor for $\mathrm{HCV}$ transmission. The risk significantly increased with non-regular female sex partners for unprotected sex. IDUs perceive the risk of transmission is less likely through sexual contact than through drug injecting behaviours which results IDUs to adopt unsafe sex behaviour than safe injection practices. In contrast, the study also found that HCV was higher among IDUs

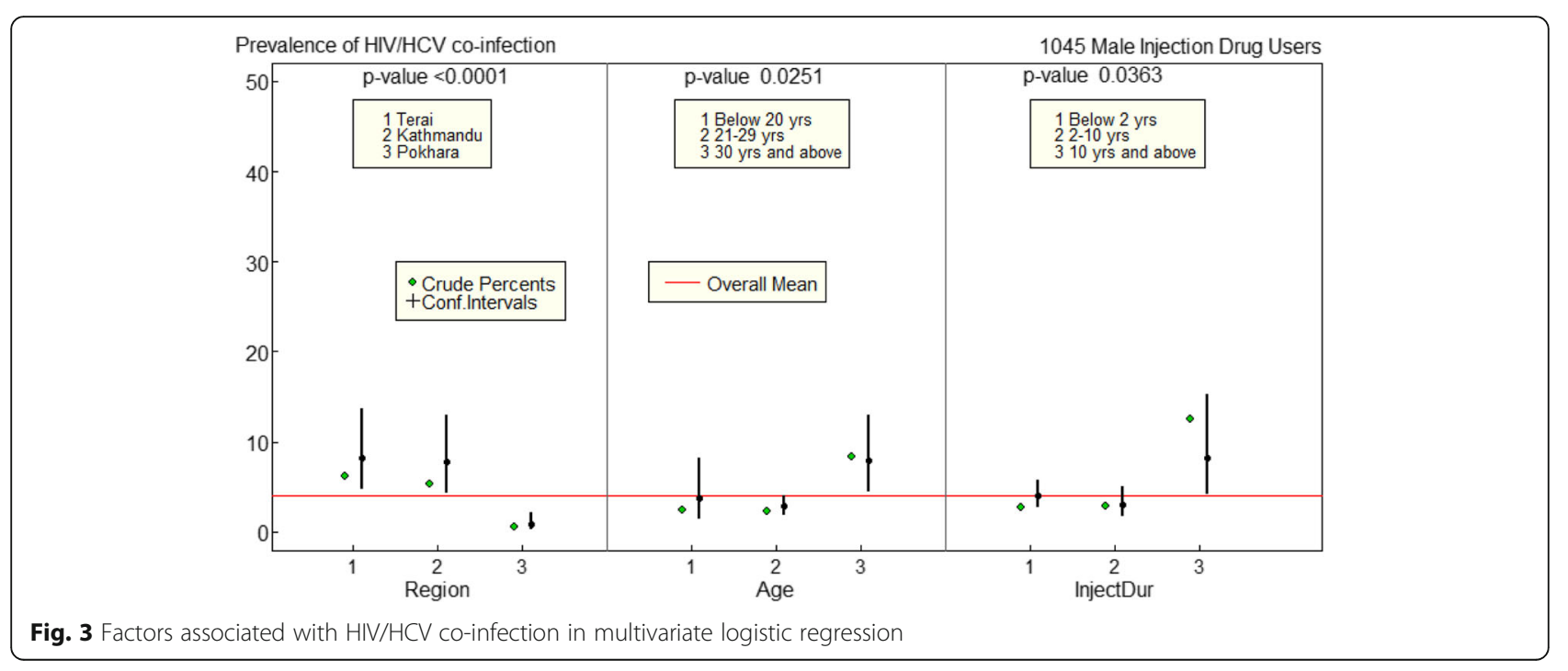



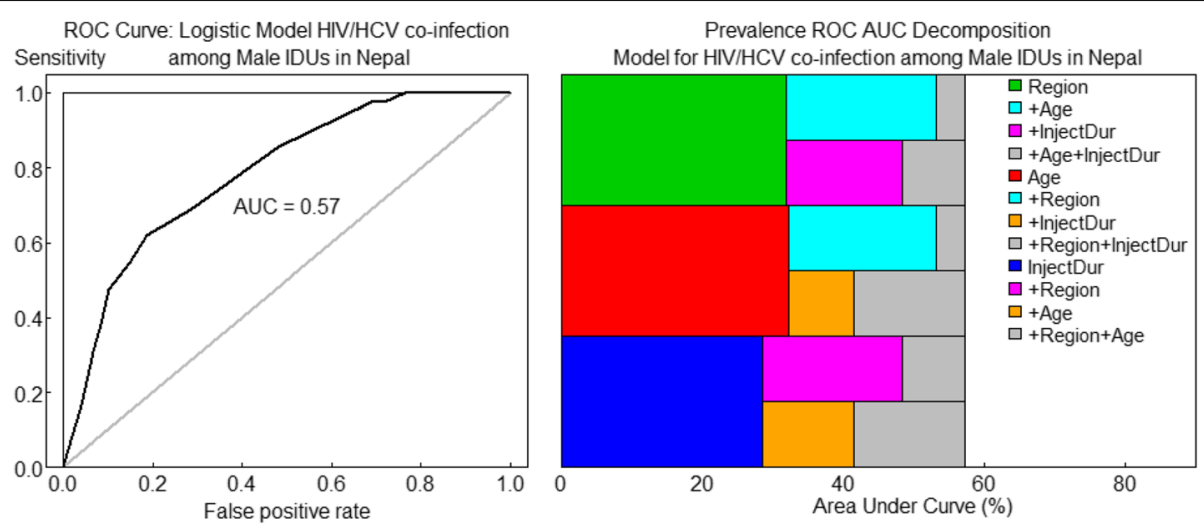

Fig. 4 ROC curve: Logistic Model for HIV/HCV co-infection among male IDUs in Nepal. Notes: InjDrug is duration of injecting drugs

who had consistent condom use with regular female sex partners. IDUs may be aware of their status and were using condoms to either avoid HCV transmission to their partners, or as self-protection from re-infection.

HIV was strongly correlated with $\mathrm{HCV}$ as $65 \%$ of male IDUs in the study were found to be HCV among HIV infected. HCV is increasing reported to be leading cause of deaths among HIV infected [1, 2, 4, 13-16]. This double burden of HCV and HIV among male IDUs need to be controlled to prevent further transmission.

As IBBS survey is cross-sectional by their intent and providence of causal relationships between the determinants and outcome is constraint in this study. This study covered social determinants and risk behaviors, while other issues related to intervention programs and drug policies were not analyzed in detail, and suggest for further studies.

\section{Conclusion}

HCV was highly prevalent among male IDUs. Injection drug use behaviors remain independent risk factors for HCV infection. IDUs therefore constitute an important source of viral infections and therefore can play a mediator for the transmission of viruses to the general population. Various intervention programs already being carried out by Nepal government for HIV related service delivery needs to be extended towards HCV infected population for the prevention of $\mathrm{HCV}$ transmission. Moreover, focussed health interventions are needed in Eastern Terai districts and IDUs with longer duration of injecting behaviours.

\section{Abbreviations}

FSW: Female Sex Workers; HCV: Hepatitis C Virus; HIV: Human Immunodeficiency Virus; IBBS: Integrated Biological and Behavioural Surveillance; MALE IDU: Male Injecting Drug Users; NCASC: National Centre for AIDS and STD Control; ROC: Receiver operating characteristic; STI: Sexually Transmitted Infections

\section{Acknowledgements}

We are grateful to participants, IBBS survey data collection research agencies and staff who support directly or indirectly for carrying out survey. We acknowledge the National Centre for AIDS and STD Control (NCASC), Teku, Kathmandu, Nepal for their approval to use data.

\section{Funding}

This research was also supported by the Postdoctoral Fellowship from Prince of Songkla University.

\section{Availability of data and materials}

This study utilized the data from Integrated Biological and Behavioural Surveillance Survey, 2015 and the data is available in the National Centre for AIDS and STD Control, Kathmandu, Nepal.

\section{Authors' contributions}

SK contributed to the concept and design, analysis and interpretation of data, drafted and revised the manuscript. MM involve in data analysis and interpretation. $\mathrm{BB}$ involved in acquisition of data and SMD involved in drafting the manuscript and revising it critically for intellectual content. All the authors read and approved the final manuscript.

\section{Authors' information}

SK: Postdoctoral Research Scientist, Department of Mathematics and Computer Science, Faculty of Science and Technology, Prince of Songkla University, Pattani, Thailand. MM: Research Officer, CREHPA, Kathmandu, Nepal

BBR: Statistical Officer, National Centre for AIDS and STD Control, Kathmandu, Nepal SMD: Director, Center for Molecular Dynamics Nepal, Kathmandu, Nepal

\section{Competing interests}

The authors declare that they have no competing interests.

\section{Consent for publication}

The Author hereby consents to publication of the work. The manuscript is original work of all authors. This manuscript has not been submitted for publication; it has not been accepted for publication and has not been published in any other journal. All authors have read and approved the final version of the manuscript.

\section{Ethics approval and consent to participate}

Ethical approval for IBBS surveys were permitted from Nepal Health Research Council (NHRC). The NHRC approval number for the survey was 1232. Ethical clearances were permitted from Nepal Health Research Council. Informed consent was obtained from male IDUs prior to the interview. There may be a risk of identifying the male IDUs through their signatures if written consent was taken. The informed consent was taken in the presence of a witness (community motivators) who then signed the consent form. Study procedure was designed to protect participants' privacy allowing for anonymous and voluntary participation. No names and personal identifiers were used in the data collection. 


\section{Publisher's Note}

Springer Nature remains neutral with regard to jurisdictional claims in published maps and institutional affiliations.

\section{Author details}

'Department of Mathematics and Computer Science, Faculty of Science and Technology, Prince of Songkla University, Pattani, Thailand. ${ }^{2}$ Center for Research on Environment Health and Population Activities (CREHPA), Kathmandu 44700, Lalitpur, Nepal. ${ }^{3}$ National Centre for AIDS and STD Control, Kathmandu, Nepal. ${ }^{4}$ Center for Molecular Dynamics Nepal, Kathmandu, Nepal.

Received: 2 January 2017 Accepted: 12 June 2017 Published online: 04 September 2017

\section{References}

1. World Health Organization. Hepatitis C. WHO facts sheet. http://www.who. int/mediacentre/factsheets/fs164/en/. Accessed 1 Oct 2016

2. World Health Organization. HIV/AIDs and injecting drug use. WHO facts sheet. http://www.who.int/hiv/topics/idu/en/. Accessed 17 July 2015.

3. Lozano R, Naghavi M, Foreman K, Lim S, Shibuya K, Aboyans V, et al. Global and regional mortality from 235 causes of death for 20 age groups in 1990 and 2010: a systematic analysis for the Global Burden of Disease Study 2010. Lancet. 2012;380:2095-128

4. Grebely J, Dore GJ. Can hepatitis C virus infection be eradicated in people who inject drugs? Antivir Res. 2014;104:62-72.

5. Nelson PK, Mathers BM, Cowie B, Hagan H, Des Jarlais D, Horyniak D, et al. Global epidemiology of hepatitis B and hepatitis $C$ in people who inject drugs: results of systematic reviews. Lancet. 2011;378:571-83.

6. Kermode M, Nuken A, Medhi GK, Akoijam BS, Sharma HU, Mahanta J. High burden of hepatitis C \& HIV co-infection among people who inject drugs in Manipur, Northeast India. Indian J Med Res. 2016;143:348-56.

7. Thein HH, Dore GJ, Krahn MD. Natural history of hepatitis $\mathrm{C}$ virus infection in HIV-infected individuals and the impact of HIV in the era of highly active antiretroviral therapy: a meta-analysis. AIDS, 2008:22:1979-91.

8. Lohse N, Hansen AB, Pedersen G, Kronborg G, Gerstoft J, Sørensen HT, et al. Survival of persons with and without HIV infection in Denmark, 1995-2005. Ann Intern Med. 2007;146:87-95.

9. Mathews GV, Dore GJ. HIV and hepatitis co-infection. Asian Biomed. 2009;3: 29-37.

10. Government of Nepal Central Bureau of Statistics. Survey report on current hard drug users in Nepal 2069. Kathmandu: Ministry of Home Affairs Drug Control Programme. p. 2014. http://www.aidsdatahub.org/Survey-Report-onCurrent-Hard-Drug-Users-in-Nepal-2013. Accessed 17 Oct 2014

11. National Center for AIDS and STD Control. National Estimates of HIV Infections in Nepal 2015. Kathmandu, Nepal, 2015.

12. Kakchapati S, Singh DR, Rawal BB, Lim A. HIV and related risk behaviour among people who inject drugs in Nepal. Asian Biomed. 2016;10:609-17.

13. Kinkel HT, Karmacharya D, Shakya J, Manandhar S, Panthi S, Karmacharya P, et al. Prevalence of HIV, hepatitis B and C infections and an assessment of HCV-genotypes and two IL28B SNPs among people who inject drugs in three regions of Nepal. PLoS One. 2015;10(8):e0134455. doi:10.1371/journal. pone. 0134455

14. Doerrbecker J, Behrendt P, Mateu-Gelabert P, Ciesek S, Riebesehl N, et al. Transmission of hepatitis $C$ virus among people who inject drugs: viral stability and association with drug preparation equipment. J Infect Dis. 2013:207:281-7.

15. Thiede H, Hagan H, Campbell JV, Strathdee SA, Bailey SL, Hudson SM, et al. Prevalence and correlates of indirect sharing practices among young adult injection drug users in five U.S. cities. Drug Alcohol Depend. 2007;91:S39-47. 25

16. Pouget $E R$, Hagan $H$, des Jarlais DC. Meta-analysis of hepatitis $C$ seroconversion in relation to shared syringes and drug preparation equipment. Addiction. 2012;107:1057-65.

17. Terrault NA. Sexual activity as a risk factor for hepatitis C. Hepatology. 2002; 36:S99-105.

18. Gunn RA, Murray PJ, Brennan CH, Callahan DB, Alter MJ, Margolis HS. Evaluation of screening criteria to identify persons with hepatitis $C$ virus infection among sexually transmitted disease clinic clients: results from the San Diego viral hepatitis integration project. Sex Transm Dis. 2003;30:340-4.

19. Alter NJ, Conry-Cantilena C, Melpolder J, et al. Hepatitis C in asymptomatic blood donors. Hepatology. 1997;26:29S-33S.
20. Tongkumchum P, McNeil D. Confidence intervals using contrasts for regression model. Songklanakarin J Sci Technol. 2009:31:151-6.

21. Chutinantakul A, Tongkumchum P, Bundhamcharoen $K$, Chongsuvivatwong V. Correcting and estimating HIV mortality in Thailand based on 2005 verbal autopsy data focusing on demographic factors, 1996-2009. Popul Health Metr. 2014;25:1-8

22. Kongchouy N, Sampantarak U. Confidence interval for adjusted proportions using logistic regression. Mod App Sci. 2010;4:1-7.

23. National Center for AIDS and STD Control. Mapping and Size estimation of most at risk population in Nepal. Kathmandu, Nepal, 2011.

24. Center on international cooperation. Getting Smart and Scaling Up Responding to the Impact of Organized Crime on Governance in Developing Countries. New York, 2013.

25. National Center for AIDS and STD Control. Integrated Biological and Behavioral Surveillance (IBBS) Survey among Injecting Drugs Users in the Eastern Terai of Nepal, Round V. Kathmandu, Nepal, 2012

26. National Center for AIDS and STD Control. Integrated Biological and Behavioral Surveillance (IBBS) Survey among Injecting Drugs Users in the Western Terai of Nepal, Round V. Kathmandu, Nepal, 2012.

27. National Center for AIDS and STD Control. Integrated Biological and Behavioral Surveillance (IBBS) Survey among Injecting Drugs Users in Kathmandu Valley, Round V. Kathmandu, Nepal, 2011.

28. National Center for AIDS and STD Control. Integrated Biological and Behavioral Surveillance (IBBS) Survey among Injecting Drugs Users in Pokhara Valley, Round V. Kathmandu, Nepal, 2011.

29. Martins T, Narciso-Schiavon JL, Schiavon LL. Epidemiology of hepatitis C virus infection. Rev Assoc Med Bras. 2011;57:107-12. (Portuguese)

30. Tan WL, Yihui G, Abu Hassan MR. Demographic characteristics and intravenous drug use among hepatitis $C$ patients in the Kota Setar district, Kedah, Malaysia. Epidemiol Health. 2015;37:e2015032. doi:10.4178/epih/ 2015032. eCollection

31. Adoga M, Banwat E, Forbi J, Nimzing L, Pam C, Gyar S, et al. Human immunonodeficiency virus, hepatitis $B$ virus and hepatitis $C$ virus: seroprevalence, co-infection and risk factors among prison inmates in Nasarawa State, Nigeria. J Infection Develop Countries. 2009:3:539-47.

32. La Torre G, Miele L, Chiaradia G, Mannocci A, Reali M, Gasbarrini G, et al. Socio-demographic determinants of coinfections by HIV, hepatitis B and hepatitis C viruses in central Italian prisoners. BMC Infect Dis. 2007;7:100.

\section{Submit your next manuscript to BioMed Central and we will help you at every step:}

- We accept pre-submission inquiries

- Our selector tool helps you to find the most relevant journal

- We provide round the clock customer support

- Convenient online submission

- Thorough peer review

- Inclusion in PubMed and all major indexing services

- Maximum visibility for your research

Submit your manuscript at www.biomedcentral.com/submit
C) BioMed Central 